\title{
Article \\ Confronting Energy Poverty in Europe: A Research and Policy Agenda
}

\author{
Stefan Bouzarovski ${ }^{1, *(D)}$, Harriet Thomson ${ }^{2}$ and Marine Cornelis ${ }^{3} \mathbb{D}$ \\ 1 Department of Geography, University of Manchester, Manchester M13 9PL, UK \\ 2 Department of Social Policy, Sociology and Criminology, University of Birmingham, \\ Birmingham B15 2TT, UK; h.thomson@bham.ac.uk \\ 3 Next Energy Consumer, Turin, 10121 Piedmont, Italy; marine.cornelis@nextenergyconsumer.eu \\ * Correspondence: s.bouzarovski@gmail.com
}

check for updates

Citation: Bouzarovski, S.; Thomson, H.; Cornelis, M. Confronting Energy Poverty in Europe: A Research and Policy Agenda. Energies 2021, 14, 858. https://doi.org/10.3390/en14040858

Academic Editor: Vincenzo Bianco

Received: 4 January 2021

Accepted: 1 February 2021

Published: 7 February 2021

Publisher's Note: MDPI stays neutral with regard to jurisdictional claims in published maps and institutional affiliations.

Copyright: (C) 2021 by the authors Licensee MDPI, Basel, Switzerland. This article is an open access article distributed under the terms and conditions of the Creative Commons Attribution (CC BY) license (https:/ / creativecommons.org/licenses/by/ $4.0 /)$.

\begin{abstract}
This paper scrutinizes existing policy efforts to address energy poverty at the governance scale of the European Union (EU) and its constituent Member States. Our main starting point is the recent expansion of energy poverty policies at the EU level, fuelled by the regulatory provisions of the Clean Energy for all Europeans Package, as well as the establishment of an EU Energy Poverty Observatory. Aided by a systematic and customized methodology, we survey the extensive scientific body of work that has recently been published on the topic, as well as the multiple strategies and measures to address energy poverty that have been formulated across the EU. This includes the principal mitigation approaches adopted by key European and national institutions. We develop a framework to judge the distributional and procedural justice provisions within the recently adopted National Energy and Climate Plans, as an indicator of the power, ability and resolve of relevant institutions to combat the causes and consequences of energy injustice. We also provide a research and policy agenda for future action, highlighting a series of scientific and decision-making challenges in the European and global context.
\end{abstract}

Keywords: energy poverty; energy justice; energy vulnerability; energy efficiency; Green Deal; low-carbon transition; European Union

\section{Introduction}

Following a long history of relative obscurity and neglect, energy poverty has gradually emerged as a central policy issue within the EU. Institutions and organizations operating at the EU level have undertaken multiple efforts to address the vulnerabilities that underpin this condition. The rise of energy poverty as a policy priority is reflected in the formulation of a series of new legal provisions within the Clean Energy for all Europeans Package (CEP), with a strong focus on housing energy efficiency [1]. The European Commission (EC) has emphasized the need for alleviating energy poverty as a key pillar in the context of a just and fair transition with the Green Deal (ibid), and the subsequent Renovation Wave [2]. What is more, the European Union has equipped itself with new and improved tools to understand, analyse and respond to energy poverty challenges [1,2]. Yet policy action at the governance level of individual Member States, regions and localities is much more uneven and limited, despite the broader impetus and steer from the EU. The significant discrepancies in the capacity and determination to confront energy poverty at the level of different sub-national jurisdictions are also reflected in the quality and extent of the mitigation programmes and strategies within these domains.

A significant body of knowledge has been developed with respect to the causes, lived experience, implications and detection of energy poverty. While initial European-level studies on the subject were far and few in between [3,4], or mainly concentrated on countries such as Ireland and the UK where the issue has a longer history of public recognition [5-7], the last five years have witnessed a dramatic upsurge in scientific interest and contributions. 
Thanks, in part, to the wide range of EU-funded research projects on the topic, there is now a much more extensive scholarly understanding of the socio-demographic factors that drive the condition, highlighting vulnerabilities along a multiplicity of axes: income, age and gender [8-11]. The roles that increasing energy prices [12] and low levels of energy efficiency $[13,14]$ play in this context has also been extensively investigated. The types of countries, regions and neighbourhoods that are most affected by energy poverty have also been explored in the literature [15], along with the geographic features of associated inequalities and vulnerabilities [16-18]. Indicator frameworks have been examined and improved, highlighting new factors that need to be taken into consideration through innovative measurement and approaches [19,20].

This paper examines existing and recent policy commitments to address energy poverty at the governance scale of the EU and its constituent Member States. Building on previous work on the topic [21-24], we interrogate the character and resolve of the recent EU and Member State efforts to address the various drivers of energy poverty. We focus on the National Energy and Climate Plans (NECPs) at the Member State level, investigating the pertinent provisions and measures that have been formulated in this domain. We also discuss changes between the draft and final versions of the NECPs as a broad-level indicator of the strength, capacity and determination of individual national governments to combat energy injustices in relation to the energy-climate interface $[25,26]$. The analysis is underpinned by a wider argument that indicators about the statistical incidence of energy poverty in individual Member States do not neatly map onto the regulatory and policy commitments within the NECPs, although the latter are not necessarily an indicator of implementation capacity or real-life policy action.

This paper is based on a broad definition of energy poverty: a condition in which a household is unable to secure a socially and materially needed level of energy services in the home [27]. Considering that the term "secure" involves both affordability and access dimensions, such a framing allows for multiple governance challenges around energy provision to be taken into account [28]. Building on this conceptual approach, the paper consists of six parts. Following the introduction and methodology description, we examine existing knowledge on energy poverty in Europe, exploring the driving forces of the problem, its socio-economic effects, territorial characteristics, as well as the relevant monitoring and measurement frameworks. The paper then moves onto an interrogation of policies and measures to address energy poverty across the EU, including principal mitigation approaches adopted by key European institutions. The next section contains an analysis of pertinent commitments in the NECPs and other official policy approaches developed by EU Member States. Here, we also evaluate the final NECP versions based on a matrix developed in line with the theoretical framing of the study. We then move onto a discussion of commitments to address energy poverty beyond the official NECP drafts and official national policies, exploring non-governmental and local initiatives, COVID-19 responses as well as the previous evolution of the NECP process itself. In the conclusion, we highlight the principal avenues for future research and policy, including the need for greater attention towards local and regional measures to combat energy poverty, the involvement of different decision-making silos, as well as the systemic challenges associated with existing monitoring and policy framings.

\section{Materials and Methods}

Methodologically, the paper consists of two elements. The first of these is a systematic review of academic articles, think tank reports, policy reports and legal acts. A total of 116 such documents were analysed, having been previously identified through several connected searches across various relevant databases. Searches were undertaken in Google Scholar and Scopus, with over 50 terms being used (examples of search terms include "energy poverty AND Europe"; "energy poverty Europe indicators"; "energy poverty Europe causes"; "energy poverty Europe consequences"; etc.). The analysis was restricted to papers published since 2015, with the exception of key contributions that informed 
the theoretical framing of the analysis. In conceptual terms, the analysis was based on established knowledge on the main institutional, political and economic embeddedness and implications of energy poverty $[22,29,30]$. Following a careful reading of abstracts identified through the searches, outputs were selected for further examination if they were deemed to contain insights relevant to the theoretical framing of the paper-involving new or influential insights regarding policies and measures to combat energy poverty in terms of both access and affordability. They were subsequently examined with the aid of interpretive analysis methods [31-33], and were grouped into three broad thematic areas, focusing on, respectively, the key characteristics of energy poverty in Europe, EU-level policy on energy poverty and energy poverty-relevant NECP provisions.

The second component of the methodology is an analysis of publicly available information in the NECPs, based on energy justice principles [29,34-36], while building on a matrix previously developed by the EU Energy Poverty Observatory, or EPOV $[1,37]$. The NECPs were analysed in ten aspects, grouped in two categories. The first of these queried the NECPs ability to provide "access to justice" [38], combining the procedure and recognition justice dimensions, such as (1) the formulation of a distinct definition of energy poverty; (2) a wider recognition of the challenge; and (3) the crystallization of the relevant indicators. The same category also included (4) the identification of local, regional and best practices; and (5) the development of effective engagement mechanisms to address energy poverty. The second group of criteria encompasses "provision of resources" $[39,40]$ in the distributional and spatial domain. Here, we judged the presence of (1) energy poverty measures through social assistance and tariff support; (2) energy efficiency investment; (3) market regulation; (4) infrastructure development; and (5) new financing models-including those provided by the EU. The 10 aspects were examined qualitatively and quantitatively, with the latter analysis involving giving a score of 1 if the criterion was partially met, and 2 if it was fully met.

It should be emphasized that the analysis centres principally on the EU and its Member States. However, there are instances where we also include neighbouring non-EU countries within the geographical region of Europe, due to their interdependence and interconnectedness with the EU-focused developments.

\section{Energy Poverty in Europe: An Overview}

Traditionally, the causes of energy poverty in the countries of the Global North have been attributed to the combination of low incomes, high energy prices and low levels of residential energy efficiency [41]. However, more recent understandings of the driving forces of this condition have introduced a wider range of dimensions to the equation, interpreting energy poverty as a systemic challenge connected to broader socio-technical and governance infrastructures. Primc et al. [42], for instance, used a fuzzy-set qualitative comparative analysis method to emphasize the importance of climate and macroeconomic development. Policy practices associated with the state, private and third sectors-as well as existing institutional structures and capacities more broadly-are also being increasingly implicated as key energy poverty factors at multiple decision-making levels [10,22,43-45]. This refers to the lack of different forms of distributional, procedural and recognition justice [46], as well as the material implications of governing choices and trajectories [47]. In this context, Scarpelini et al. [18] emphasize the mediating role of social workers in the implementation of regional policies aimed at alleviating energy poverty, while Streimikiene et al. [48] highlight the need for "determined, continued, and multifaceted actions" (p. 18) at the EU level. The joint agency of policy, planning and infrastructure-including poor energy efficiency and issues of energy access - is powerfully uncovered in Teschner et al.'s [30] study of "extreme" energy poverty in the urban peripheries of Romania and Israel.

Among socio-demographic factors, the decisive role of gender inequalities has received particular attention [49], with Petrova and Simcock [11] contending that energy poverty is differentially experienced along gender lines, both in terms of "household practices of responding to and resisting energy poverty" (p. 1), and the emotional labour of 
living in, and responding to, the lack of adequate energy services in the home. Importantly, their research highlights how gendered vulnerabilities-as well as associated forms of political agency and emancipation-surface as a result of household strategies to confront domestic energy deprivation. Gender, therefore, is not only a driver of energy poverty, but also a key element of energy injustices as they relate to everyday life.

The detrimental impacts on human health and well-being exerted by energy poverty are extensively known and documented. Thanks to a comparative study of 32 European countries, Thomson et al. [50] highlight the well-documented negative effects of energy poverty on respiratory and circulatory systems, as well as bad self-reported health, "poor emotional well-being, and likely depression" (p. 17). Focusing on Southern European countries, Oliveras et al. [51] underline the uneven distribution of energy poverty patterns along different axes of inequality — such as gender or social class-alongside the greater use of health services and medications. A rare paper exploring the relationship between energy poverty and health outcomes in Turkey [52] sheds further light on the socio-demographic and household-level determinants of poor health status, as well as the crucial role that poor housing and inadequate energy efficiency play in this context. The causes and consequences of energy poverty are also increasingly studied through the lens of social relations with "family, friends, agencies and distant others" [53]—contingencies that are shown to both shape, and shaped by, energy access to energy services and energy use.

In terms of the lived experience of energy poverty, growing attention is being paid to a wider range of energy services, beyond heating. Even if a number of energy poverty definitions—-such as those for Wales and Northern Ireland for example [54] —are primarily focused on inadequately warm homes, there is now rising interest in, and awareness of, other aspects of domestic comfort and well-being that may be affected by energy poverty. For example, Thomson et al. [55] explore why and how some households are forced to live in inadequately cool homes during periods when outdoor temperatures are high. The deleterious effects of climate change-including warmer weather, more frequent heatwaves, altered wind and humidity patterns, as well as Urban Heat Islands (UHIs) —are a key factor in this context, in addition to the overall condition of the housing stock and the provision of adequate outdoor amenities [56,57]. In this context, it is worth noting Sanchez-Guevara et al.'s [58] examination of population vulnerability towards summer energy poverty-via case studies of Madrid and London-in which the authors emphasize, inter alia, the major contribution of inappropriate solar shading, inefficient ventilation and UHIs. Petrova [28] discusses the phenomenon of "lighting poverty" in the context of the Greek austerity, positioning the lack of light at the nexus of political metaphors, governing strategies and domestic material conditions. The relationship between energy and transport has also entered the debate, emphasizing wider interdependencies among the different forms of exclusion, infrastructural development, environmental policy and energy costs $[17,59,60]$. As highlighted by Kerr et al. [22], mobility poverty was a key feature of the "Gilets Jaunes" ("Yellow Vests") protests in France.

The spatial variation of energy poverty in Europe has also been extensively studied and described (Figure 1). Earlier research on the topic identified Eastern and Southern European countries as particularly vulnerable, for distinct regions-high levels of general income poverty, inefficient housing, inadequate infrastructure development and various governance challenges [3,4]. Bouzarovski and Tirado Herrero [15] interpret the macro-level geographies of energy poverty through the lens of the "energy divide", a concept that seeks to capture the significant core-periphery gap within the European Union when it comes to the interplay of energy transitions, regional inequalities and general poverty trends. 


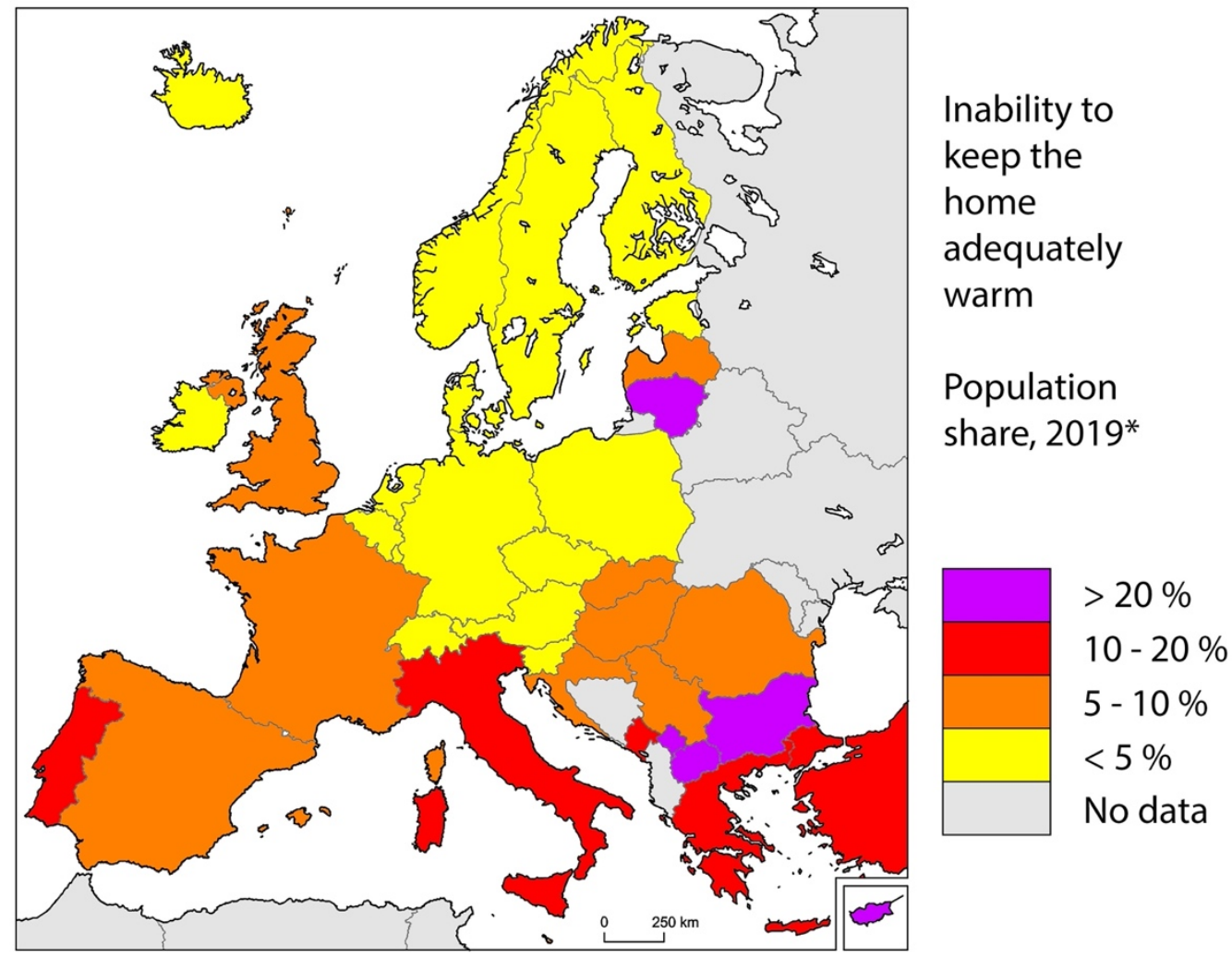

Figure 1. Spatial variation in energy poverty in terms of the inability to achieve adequate thermal comfort. Data source: EU-SILC survey. Map by Stefan Bouzarovski, outline map of European borders courtesy of http://www.hist-geo.co.uk/.

* Note: Kosovo, UK and Iceland data are from 2018.

Large-scale territorial patterns are underpinned by a finer grain of geographical variation. Studies at the regional and national level are starting to capture some of the more specific socio-spatial aspects of the problem. In the Italian case, Besagni and Borgarello [61] argue that geographical differences among regions are the main variable in explaining the distribution of households affected by energy poverty. The use of a composite indicator to assess territorial disparities in household vulnerability to energy poverty has led Murias et al. [16] to conclude that understandings of the impact of energy poverty in Spain need to focus on "dimensions different from the economic ones, such as the decentralization of energy infrastructures and improvement of renewable energy access" (p. 19). For Portugal, Horta et al. [62] find that "more affluent regions and households have lower levels of vulnerability to energy poverty" (p. 8), although they also note that many households feel it is "normal and acceptable to feel thermal discomfort at home" (ibid). Bouzarovski and Tirado Herrero [63] established that there are significant regional differences in energy poverty levels within Poland, Czechia and Hungary, often relating to wider economic inequalities (also see [64] for further detailed work on Poland). There are divergent opinions about the relationship between energy poverty patterns, on the one hand, and the urban-rural divide, on the other; while Bouzarovski and Thomson [64] uncover significant urban energy poverty levels in the inner cities and neighbourhoods of a number of Central and Eastern European cities, Scarpellini et al. [65] argue that, in Spain, "energy poverty is less acute in the households located in rural areas" (p. 320). This conclusion is countered by Katsoulakos and Kaliampakos [66,67], who establish extensive vulnerabilities in mountainous rural Greece, as well as by Sokołowski et al. [68], who underline the pertinent challenges faced by Polish rural regions.

There has been significant progress on the development of energy poverty indicators. Much of the literature on the subject claims that energy poverty cannot be described or captured via a single measure, and indeed this is the approach adopted by EPOV [69]. 
However, a number of authors have attempted to develop composite indicators based on the available data [12,68,70-72]. The energy vulnerability framing [73], operating with six relevant factors (access, affordability, flexibility, energy efficiency, needs and practices), has provided a basis for the development of multiple measurement approaches. Based on this paradigm, Thomson et al. [20] emphasize the "limited availability of appropriate data and indicators, and lack of consensus on how energy poverty should be conceptualized and measured" (p. 879). Different researchers provide different responses to the measurement challenge, with Castaño-Rosa et al. [19] arguing in favour of a multi-indicator approach that distinguishes among "indicators based on household income and expenses; those based on self-reported household conditions; and initiatives for the assessment of the risk" (p. 45) of energy poverty. Acknowledging that "no measurement is perfect" (p. 14), Sareen et al. [74] claim that policy action in its very essence cannot encompass or address all varieties of energy poverty. The authors seek to problematize measurement practices in this domain, while emphasizing the politics of data and scale in the institutionalization of data and metrics. They propose five dimensions to capture the "energy poverty metrology" (p. 26), focusing on, respectively, historical trajectories, data flattening, contextualized identification, new representation and policy uptake.

\section{Combatting Energy Poverty via EU Policy}

An extensive body of literature has examined policy activities aimed at addressing energy poverty at the EU and national governance scales. Researchers working in this vein have highlighted the intricate and thorny historical path towards an integrated EU policy in the energy poverty domain $[21,24,75,76]$, while emphasizing that further EU leadership is needed to "solidify legislation and catalyse action" [77]. Still, the recognition that "energy poverty needs to be addressed differently across member states" (ibid) has been reflected in national-level research on the topic. A comparative investigation of energy poverty policies and measures across 5 EU countries, undertaken by Kyprianou et al. [23], has found that regional approaches are more effective in energy poverty alleviation compared to those at the national level. The same study also emphasizes that countries with a "wide range of measures perform better" (p. 46) than those who have a more limited policy arsenal, while tracing back conceptual ambiguity around energy poverty to the nature of EU directives.

Lakatos and Arsenoupoulos [78] use a SWOT (strengths, weaknesses, opportunities, threats) approach to scrutinize the existing financial instruments to tackle energy poverty in households, emphasizing that "policy makers should consider the affordability element, the nature of financing, the project size and the inclusion of technical assistance into the specific schemes" (p. 16) in this context. For Austria, Seebauer et al. [79] underline that "socio-economic conditions and housing market structures need to be incorporated in policy design" (p. 304), with inter-ministerial collaboration helping to strengthen the integration of policies across the climate and social sectors. Karásek and Pojar [80] reach broadly similar conclusions in the case of Czechia, emphasizing the need for a clear and integrated national strategy on the issue. However, action to resolve the issue can extend beyond the national and regional levels, while including a wider variety of stakeholders: using illustrative examples from Italy, France, Catalonia and England, Creutzfeldt et al. [81] examine the importance of non-governmental organizations in providing a form of "nodal governance" (p. 635) that radically transforms both the power calculus and everyday experience of vulnerability. Of note are also the increasing numbers of different EU-funded projects on energy poverty, involving a wide array of actors, methods and sites of action [82,83].

Energy poverty is currently mentioned in various EU directives and Member State policies. It is also being gradually integrated in various local government programmes. Importantly, a diverse trans-local polity of active practitioners, advocates and researchers is now committed to addressing the issue. The need for a pan-European strategy to tackling energy poverty has been continuously gaining support since 2015 at least. The EC Communication on the Energy Union [84] laid the groundwork for a wider effort to "protect vulnerable consumers" while recognizing the different causes of energy poverty. 
EPOV-heir, in many ways, to the Vulnerable Consumers Working Group of the European Commission [85]—commenced its work in 2016 by providing a new series of decision-support tools, including common indicators and databases. On the legislative front, a key push for common action was provided, inter alia, by three documents: (1) the "Energy Poverty Handbook" supported by Green European Parliament Member Tamás Meszerics [86]; (2) the European Parliament resolution "on delivering a new deal for energy consumers" [87]; and (3) the European Parliament's Socialist and Democrats' group manifesto on the subject [88]. At the same time, the European Economic and Social Committee, and the Committee of the Regions-two key advisory bodies at the European scale-provided extensive support for broader energy poverty policies [89,90].

All of the above helped establish a clear impetus among EU-level stakeholderswhether from government, industry or the third sector-towards the adoption of integrated and ambitious measures. One of the main areas of consensus was the need to improve energy efficiency in the residential sector through energy policy and economic development measures. Consequently, the CEP set of directives and regulations, presented by the EC in 2016 and adopted in 2018-2019, provided a clear blueprint for combating energy poverty. Relevant provisions were integrated into multiple legislative acts. New obligations also applied to Member States as well as European institutions. For the first time, European policymakers agreed on a common definition of energy poverty, linked to economic and non-economic factors. Article 28 of the Market Design Directive refers to low incomes and "critical dependence on electrical equipment for health reasons, age or other criteria" [91], as well as the energy performance of homes. Member States were asked to define the concept of "vulnerable consumers", referring to "energy poverty and, inter alia, to the prohibition of disconnection of electricity to such customers in critical times" (ibid). Energy vulnerability in this context "may include income levels, the share of energy expenditure of disposable income, the energy efficiency of homes, critical dependence on electrical equipment for health reasons, age or other criteria" (ibid). Even if the principle of subsidiarity is still applied to Directives, the Governance Regulation (2018/1999) requires Member States to present specific national targets in their national energy and climate plans (NECPs) and monitor, analyse, understand and reduce energy poverty, if the number of energy-poor people is deemed "significant" [92]. However, the more specific meaning of "significant" was poorly defined at the time [1].

With the European Green Deal, presented in 2019, as well as the Recovery Plan following the COVID-19 lockdowns in the spring of 2020, the EC tied energy poverty to the idea of "just and fair" energy and climate transitions, which aim to "leave no one behind", while making Europe the first "climate-neutral" continent by 2050. The issue of climate taxation was particularly critical in this regard. As indicated in the Impact Assessment accompanying the EC Climate Plan, "as a possible negative outcome of the transition, households in the lower-income deciles might have to compensate higher energy expenditures by reducing consumption of other goods. As energy costs are projected to increase, energy poverty could intensify if not adequately addressed" [93]. The Commission, therefore, called for "coherence" between environmental and social policies and citizens" participation in the decision-making process, to ensure that they take ownership of the transition. This is perhaps one of the effects of the aforementioned "Gilets Jaunes" movement, as well as the protests against rising utility bills in Bulgaria in 2013 [94]. The EC acknowledged that issues linked to "end of the month" and "end of the world", a slogan widely used by the "Gilets Jaunes", are no longer mutually exclusive but rather can be treated with an equal level of urgency. In response to previous legal and policy commitments, the EC offered a series of more tailored recommendations, so as to aid energy poverty alleviation across Europe. The resulting guidance-published in the form of specific recommendations and a staff working document-provides Member States with detailed insights on how to define, measure and address energy poverty, while evaluating best practices to address the problem at the national scale $[95,96]$. 
Another critical large-scale EU tool to combat energy poverty has been the Just Transition Fund, which nominally aims to provide assistance to the people, regions and sectors most affected by the climate transition-due to their high dependence on fossil fuels-in shifting to a low-carbon economy. The fund's budget is 17.5 billion euros, resourced from both the public and private sector. EU decision-makers hope that this scheme will help companies and workers employed in carbon-intensive industries to be trained in the building sector or renewable energies, for example. The aim is not only to respond to climate challenges-as carbon neutrality and the reduction of greenhouse gas emissions are top priorities for the EU-but to reduce mass unemployment and improve the overall quality of life through housing interventions.

Already central to the CEP, the quality of the building stock is another pillar of the Green Deal and the 2020 Recovery strategies. The mass renovation and improvement of the energy performance of the European building stock is interpreted as a silver bullet for solving the social, economic and environmental challenges associated with energy injustice. The EC has thus presented a "Renovation Wave" aimed at refurbishing the building stock so as to "pave the way for a decarbonized and clean energy system" [2]. This massive renovation plan should help the EU "address the twin challenge of energy efficiency and affordability in the building sector" [97]. The objective is to "at least double the annual renovation rate of existing building stock" [98]. As a whole, the Renovation Wave is expected to exert a significant impact on the renovation of low-income and social housing. A European Parliament report adopted in September 2020, and promoted by a Green MEP, called for the Renovation Wave to prioritize energy-poor and vulnerable people [99]. However, the genuine commitment of Member States to the programme-and its real-world impact-has yet to be seen: at the end of September 2020, only half of EU countries had published their comprehensive long-term renovation strategies, otherwise deemed to be an "important input" for the Renovation Wave. The Energy Performance of Building Directive (2018/844/EU) required Member States to provide them by March 2020 [100].

\section{Strategies and Measures to Combat Energy Poverty within the NECPs and National State Policy}

The majority of draft NECPs—in their first versions published in 2019-failed to link energy efficiency and poverty mitigation policies, even if such documents constituted the basis of both a national and pan-European understanding [37]. Since then, the prominence of energy poverty concerns has increased, and the final NECP versions demonstrate additional policy efforts by Member States. However, a mixed approach towards energy poverty is still pervasive. Most governments have not adopted an official definition, and comprehensive social policy measures, coupled with bold actions in the health, infrastructure and housing sector-beyond renovation-are still missing [1]. Attention is still primarily given to economic factors and the issue of affordability, while dismissing more complex and structural dimensions such as summertime cooling, transport, gender or ethnic minorities.

Policy efforts have frequently disregarded disconnections from energy supply, and more widely, the absolute absence of electricity grid access. It is estimated that more than 30,000 people in Romania are not physically connected to the electricity network [101]. In 2019, the Right to Energy Coalition pointed out that seven million European households received disconnection notices each year [37]. NECPs drafted before the COVID-19 outbreak rarely paid any attention to this challenge. However, with the lockdowns in the spring of 2020, Member States had to review their policies very quickly [1], because many households were forced to stay at home or lost their jobs as a result of the health emergency and the sudden economic downturn [102]. Housing issues, in general, have since then attracted more attention, including completely overlooked challenges, such as overcrowded accommodation.

All of this confirms the importance of integrated energy poverty policies in the Renovation Wave, which are seen as a stepping point for encouraging a bottom-up recovery 
process, based on local-level resources and efforts [99]. Evidence from EPOV shows that the incidence of energy poverty differs significantly from country to country and within each Member State. Northern and Western European states experience lower levels of energy poverty than those to the East or South [37]. The large scale geographical distribution of the energy poverty problem is perhaps one of the reasons why governments with a lower incidence of energy poverty - including Germany, Denmark or Sweden - treat the predicament as part of the more general income poverty domain, and advocate in favour of addressing it via social policy. Yet countries that contain the highest levels of energy poverty have not necessarily developed the most ambitious policies. Both the NECP and state policies recently put forward in Bulgaria, for example, show that the energy poverty challenge is still treated in a rather superficial manner. This country only proposes direct financial assistance to support domestic incomes or the payment of energy bills, while failing to connect energy efficiency programmes to the challenges faced by energy poor households [1].

In terms of the specific energy poverty provisions contained within NECPs, different countries across the EU have been following different speeds and pathways. Spain is one of the few Member States committed to implementing an ambitious and comprehensive programme. This country has been gradually developing its policy framework over a prolonged period of time, with innovations starting from the regional and local levels. For example, in 2015, the Parliament of Catalonia voted on a law on energy poverty, which regulates, among other items, the thorny issues of disconnections and debt. The regional law stems from a range of civil society initiatives, and can be particularly traced back to the active advocacy and practical work of the "Alliance against energy poverty" [103]. At the national level, although a range of instruments were already present, a very comprehensive strategy was adopted in 2019. The strategy involved extensive consultations with stakeholders and drew heavily on the recommendations and indicator frameworks proposed by EPOV. However, it has been noted that this new strategy could have exhibited bolder ambitions in the energy efficiency domain [104].

Most NECPs have developed a detailed overview of the energy poverty challenge and the measures to address it at the national scale. This is true even for Member States who do not consider or recognize energy poverty as a distinct phenomenon. Such is the case in the NECPs of Denmark, Estonia, Finland, the Netherlands and Malta. Sweden is the only country to have judged that energy poverty should not be covered in its NECP, opting out of providing an assessment of the current state of affairs at the national level. Still, as was noted above, most countries have not formulated an official national definition. Among those who have done so, the definition is not necessarily official: Italy and Malta, for example, define energy poverty only within the framework of the NECP. Still, official definitions with a broader remit can be found in a number of NECPs, including those of Austria, Cyprus and Spain.

Most NECPs have also delineated a range of official indicators aiming to capture the social, economic and environmental effects of energy poverty on their territories. The four "primary" indicators identified by EPOV—high energy burdens, low absolute energy expenditure, arrears on utility bills and self-reported inability to keep the home adequately warm-are used in the NECPs of Denmark, the Czech Republic and Romania, who combine them with EU-SILC data to generate estimates of the size and urgency of the energy poverty challenge. Only France and Luxembourg discuss the interface between energy and transport, while the problem of space cooling associated with summertime energy poverty is, overall, absent from the entirety of the NECP corpus. Austria, Belgium, France, the Netherlands and Denmark are among the countries that connect energy affordability issues with the low-carbon transition.

The key practical, scientific and policy impacts of Horizon 2020-funded projects in the domain of energy poverty are highlighted in the Finnish, Latvian and Lithuanian NECPs. Other EU funds, as well as regional co-operation and cohesion policies, are discussed in the NECPs developed by Belgium (the Region of Brussels), in addition to Bulgaria, 
Croatia, Greece, Italy and Poland. There is a strong emphasis on energy efficiency and housing renovation policies across all plans, both with regard to efforts aimed explicitly at vulnerable groups, as well as the general population. Thus, mentions of housing renovation objectives and programmes can be found in the NECPs of Austria, Belgium, Bulgaria, Croatia, the Czech Republic, Cyprus, Denmark, Estonia, Finland, France, Greece, Hungary, Italy, Latvia, Lithuania, Poland, Portugal, Slovenia, Slovakia and Spain. There is not much detail, however, with regard to the treatment of energy poor households within these policies. What is more, Cyprus, Denmark, Estonia, Latvia, Malta, the Netherlands Slovakia and Sweden's NECPs underline that their "Long-Term Strategy for Renovation", as per the requirements of Energy Performance of Buildings Directive 2018/844, will be contained in further dedicated documents to be published in the future.

Additionally, there are a number of notable and specific features that deserve a mention:

- The French NECP offers an exhaustive description of energy efficiency and housing refurbishment approaches aimed at both energy-poor households and the social housing stock. This document also includes an overview of relevant stakeholders in the sector, as well as institutional modalities and financing mechanisms.

- While the Croatian, Estonian, Greek and Spanish NECPs elaborate the link between housing renovation, energy poverty and vulnerable households, the Italian NECP underlines the continued room for future policy measures in this domain.

- Several Member States-including Austria, Croatia, Belgium and the Czech Republicdiscuss the implementation of policy measures at the sub-national scale. This is principally connected to ability of regulatory and governance structures to implement such measures, whether in terms of energy efficiency and retrofitting policies (Belgium), social housing programmes (Austria) or local capacity-building (Croatia).

The NECPs also elaborate earmarked energy payment or bill support, including social tariffs (in Belgium and Portugal), bonuses and vouchers (Cyprus, Italy, France), as well as energy, winter or heating allowances (Bulgaria, Denmark, Lithuania, Luxembourg and Poland). Regulated prices are used in Hungary, Bulgaria and Italy, although the resulting subsidy is not specifically targeted at vulnerable households.

Many NECPs also highlight wider energy equity and consumer protection measures, principally in the context of energy market and governance participation. These include strict reminder procedures or obligation to contract (Austria); bans on winter disconnections and energy efficiency advice (Finland); wider energy efficiency schemes (Malta); tax policies (Netherlands); and support for economic growth and employment via dedicated programmes (Slovakia). The Maltese and Polish NECPs are among the few to have made an explicit link between energy infrastructure investment, on the one hand, and improved energy access, on the other.

A quantitative analysis of the NECPs based on the methodology described previously (see Figure 2 for results) shows a broad-level relationship between two composite axes:

- "Access to justice" on the x-axis, involving five procedural and recognition dimensions: the presence of an official definition of energy poverty, recognition of the challenge, presence of relevant indicators, identification of best practices and effective public engagement mechanisms;

- "Access to resources" on the y-axis, involving a further five distributional and spatial justice aspects: social assistance and tariff support, energy efficiency investment, market regulation, infrastructure development and new financing models.

To reiterate, each NECP was scored on the 10 aspects: countries received a score of 0 (not met), 1 (partially met) or 2 (fully met) for each criterion, depending on the extent to which it was addressed. It was found that eight countries-Belgium, Cyprus, Lithuania, Italy, Malta, Romania, Spain and France-scored relatively high on both axes, signalling well-developed energy poverty policies across a variety of decision-making registers. A distinct group of Southern and Eastern European Member States were stronger in distributional terms: their focus has been more on the more tangible causes and consequences of 
energy poverty-around energy efficiency and incomes. Countries with more developed social and energy policy mechanisms have tended to score better on the procedural axis. This suggests that they have prioritized governance capacities to combat energy poverty.

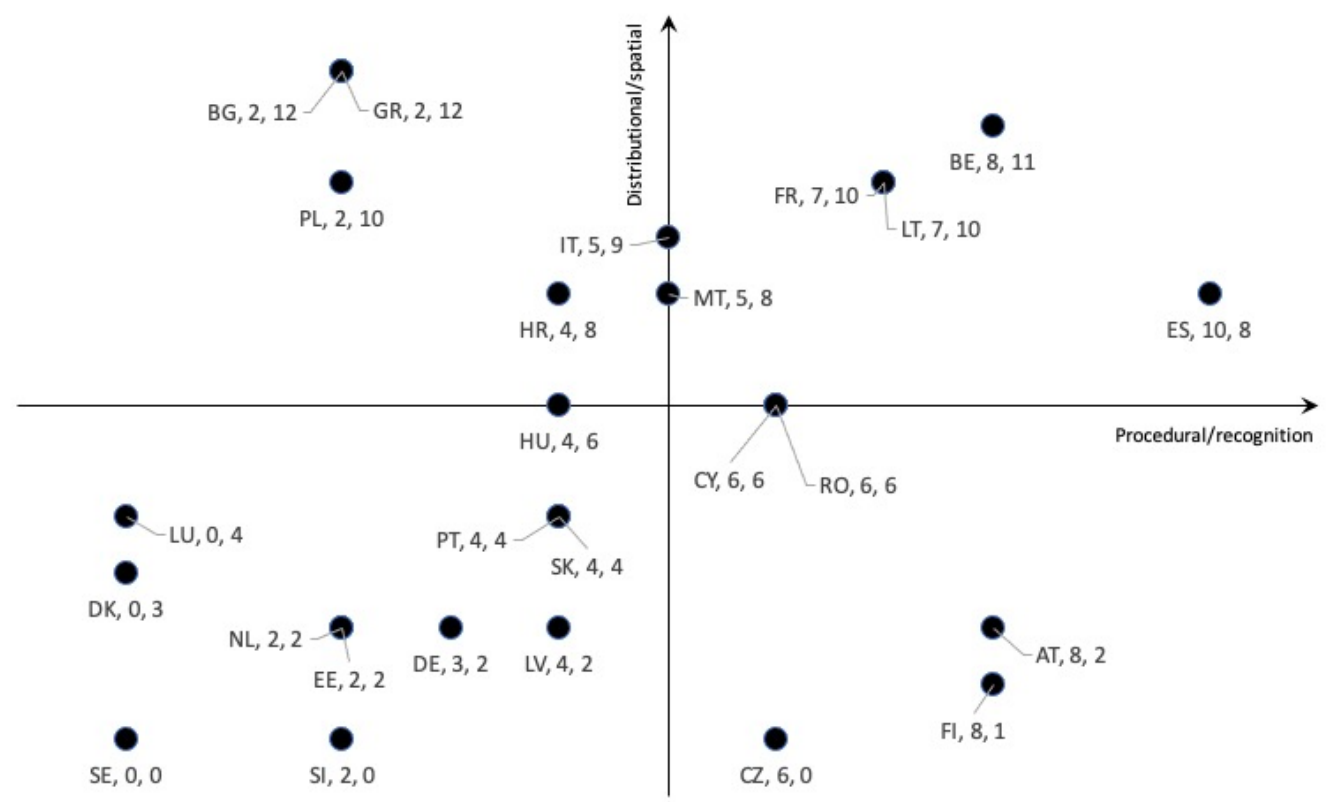

Figure 2. An appraisal of the National Energy and Climate Plans (NECPs) based on "access to justice" (x-axis) and "access to resources" (y-axis). See the Supplementary File for the individual country scores per criterion.

\section{Energy Poverty Action Outside the Final NECPs and National Government Measures}

Well before the adoption of extensive EU-level policies, Pye et al. [24] noted that Member State-level national actions varied, and had been "tailored to national circumstances characterized by the policy approach, extent of market liberalization, and physical characteristics of household energy and building stock" (p. vi). The situation has not changed much since, and significant discrepancies are still visible at the national level. Across Europe, the binding of energy, climate and social ambitions has often occurred thanks to the work of organizational and political structures beyond the formal framework of the nation state, or for that matter, the official and final NECPs versions reported to the EC.

A paradigmatic example is provided the French observatory on energy "precariousness" in 2011. Its establishment benefitted from the RAPPEL fieldwork-a dynamic assemblage of stakeholders from different backgrounds-as well as the "Rénovons!" network on housing retrofitting. RAPPEL and "Rénovons!" have been working together towards the eradication of 'thermal sieves' - understood as housing that is extremely energy-intensive. In recent years, the two initiatives have been instrumental in persuading policymakers to adopt more ambitious laws and programmes, particularly in the domains of climate mitigation and housing renovation [1]. However, similar organizations in other European countries have been struggling with the constant lack of financial support, which has often prevented the real life implementation of the stated ambitions [105].

Another vignette comes from Belgium, where energy poverty mitigation has been relying on well-defined regional decision-making architectures. Networks of actors at the federal level are co-ordinated by private initiatives, such as the King Baudouin Foundation. Even polities in which energy poverty was previously not widely recognized are starting to pay attention to the issue, in addition to creating dedicated monitoring and action frameworks. This is the case in Italy, where, while waiting for an official national body of this kind, the University of Padua and the Bank of Italy have formed an energy poverty observatory to foreground existing instruments and provide new measurement frameworks [1]. 
In many European countries, a number of innovative local and regional schemes have managed to mobilize municipalities and stakeholders from various non-governmental sectors, including public advocates, charities and volunteers active in the field. As was pointed out above, non-governmental actors often serve as key "bridging agents" in terms of facilitating, enabling and articulating grassroots energy poverty alleviation mechanisms. Relevant examples include:

- Projects such as "Eco-Habitat" in France, "Papillon" in Belgium or "Caf-Acció" in Spain, undertaken and led by civil society partnerships and developed without the initial support of public authorities, show that it is possible to create practical responses tailored to the specific needs of local communities [1,81]. Such bottom-up initiatives have a significant potential to complement public action at the regional, national and international scales.

- As highlighted in the NECPs, European funds from the Horizon and Interreg programmes have been instrumental in the financing of many pilot projects. For instance, as noted in Bouzarovski et al. [1], the Horizon 2020 STEP-IN project (2018-2020) has set up "living labs" in Manchester (UK), Metsovo (Greece) and Nyírbátor (Hungary). The project STEP (2019-2021), also a Horizon 2020 initiative, has attracted the attention of policymakers in the countries where it is implemented, notably Cyprus, Latvia, Lithuania and Portugal.

- Action has also been articulated outside the Horizon 2020 framework. The POWERTY (2019-2023) project has been financed by regional development funds, providing novel regional-level learning pathways in the implementation of renewable energy resource policies aimed at vulnerable groups.

Looking outside the specific national energy poverty polity, responses to the COVID-19 crisis-otherwise known to have exerted significant energy justice-related pressures [102,106,107] — provide a good indicator of the governance capacities to address the problem across Europe (Table 1). Data from the crowd-sourced map of energy poverty measures developed by the ENGAGER network (http: / / www.engager-energy. net/covid19/) offers insights into the differences among European countries in this regard. Based on the source data and classification of COVID-19 measures developed by the authors [108], it is possible to examine how many COVID-19 policies are cumulatively present in different groups of European countries, in relation to the severity of energy poverty. The categories presented in Figure 1 (in terms of the percentage of people who are reporting an inability to keep the home adequately warm) can be used as a proxy for the size of the energy poverty problem in each country. To summarize the outcome: the greatest number of measures were found in countries with relatively low percentages of people who are self-reporting insufficiently warm homes, although, on average, countries with a relatively high value of this indicator (between 10 and 20) had the highest number of measures per state. The majority of policies were in the regulatory domain (involving government and utility policies), with disconnection bans being most represented in relatively better-off nations in energy poverty terms.

Last but not least, it should be noted that the initial drafts of the NECPs-presented in 2019-are presently available online, alongside the Commission's feedback. The extent of any changes and modifications between the initial and final versions also opens a window into wider national governing commitments and capacities in the energy poverty domain $[109,110]$. In the draft versions of the NECPs, most countries had failed to define energy poverty or provide an extensive analysis of the drivers of the condition. It was frequently mentioned that energy poverty is not an energy policy question, thereby absolving governments from taking specific action or developing tailored programmes.

- The draft NECPs of Denmark, Finland, Germany, the Netherlands, Malta and Sweden argued that energy poverty cannot be distinguished from income poverty, and therefore can be addressed via general social policy. 
- The NECPs of Lithuania and Hungary-countries characterized by an extensive sociodemographic extent of energy poverty - underlined how existing measures (including price regulation in Hungary), are sufficient to confront the challenge.

- Of note in terms of the progress along the revision trajectory is the Lithuanian NECP, where the final document provides a much more comprehensive suite of indicators, definitions and policies.

- The final versions of the Spanish and Hungarian NECPs also offer a much wider suite of energy poverty indicators and measures compared to their initial drafts.

Table 1. Energy justice-focused policies during the COVID-19 pandemic in groups of European countries with different rates of energy poverty, based on the data and classification developed by Hesselman et al. [108]. See the Supplementary File for individual country listings.

\begin{tabular}{ccccc}
\hline $\begin{array}{c}\text { Share of the Population Reporting an Inability } \\
\text { to Keep Their Homes Warm in 2019. Total } \\
\text { Number of Measures in All Countries. }\end{array}$ & $\mathbf{<}$ & $\mathbf{5 - 1 0}$ & $\mathbf{1 0 - 2 0}$ & $\mathbf{2 0}$ \\
\hline Regulatory action & 7 & 6 & 6 & 3 \\
\hline Subsidies on energy bills & 1 & 1 & 0 & 1 \\
\hline Other measures & 1 & 1 & 2 & 0 \\
\hline Disconnection ban & 6 & 5 & 1 & 2 \\
\hline Payment arrangements & 5 & 7 & 8 & 2 \\
\hline Total & $\mathbf{2 0}$ & $\mathbf{2 0}$ & $\mathbf{1 7}$ & $\mathbf{8}$ \\
\hline Measures per country & 1.25 & 2.22 & 3.40 & 1.60 \\
\hline
\end{tabular}

All of the evidence reviewed in this section points to the growing alleviation of energy poverty via a wider and more innovative range of instruments, including multi-level funding programmes, consumer empowerment, decentralized generation, community energy and alternative business models.

\section{Conclusions}

This paper has discussed recent developments in the European policy arena with respect to the governance and amelioration of domestic energy inequalities. We have examined efforts to tackle energy poverty across a variety of decision-making scales, both in terms of EU legislative and strategic efforts and national approaches towards vulnerable households. Special attention was provided to the specific regulatory provisions and measures foreseen within the NECPs as part of the formal requirements laid down by the CEP. We have found, overall, that both the EU and its constituent Member States have made significant progress in developing a robust decision-making framework to mitigate energy poverty, even if the general picture at the national scale is highly uneven. What is more, owing to the statutory set-up of energy poverty amelioration programmes, the structural injustices that lead to energy poverty generally remain outside the remit of most policy efforts. Here, we would corroborate the findings of the EPOV's assessment: "many NECPs have missed the opportunity to foreground and support local action, while proposing more ambitious energy poverty alleviation measures where they might be needed" [1].

Despite the significant progress that has been made in the scientific understanding and policy framework around energy poverty, a number of key issues remain on both fronts-in Europe and beyond. In terms of the former, there is a clear necessity to translate generic commitments made at the EU and national levels into decisive energy policy action and transformative housing upgrades in particular. That will require not only financial resources committed via the EU or state funds, but the co-operation and involvement of stakeholders from all relevant sectors: social policy, housing, health, business, planning and regional development.

To date, the trajectories followed by the relevant EU policies and platforms such as the NECPs have been characterized, broadly, by the limited participation of decision-making 
forces and actors outside the energy sector. What is more, national policy frameworks display a relative lack of innovative participatory mechanisms to engage vulnerable citizens in the design and implementation of relevant measures and programmes-especially in terms of the "hard to reach" [10,46], who face a complex array of institutionally and socially entrenched difficulties.

The possible future expansion of existing, and establishment of new, national energy poverty observatories may help overcome some of these hurdles, especially if the coming years see an improvement in the quantity and quality of available evidence on energy poverty. Here, one area that demands particular attention is the link between energy inequalities, on the one hand, and hitherto relatively neglected contingencies such as gender, disability, ethnicity, transport and summertime cooling, on the other. There is also a pronounced need to capture regional- and urban-level variations in energy access and affordability, given the rising prominence of urban decarbonization agendas across Europe and the world.

Even more challenging, however, are the scholarly questions raised by the rising prominence of energy poverty within the policy sphere. We would identify four principal directions for future work in this regard.

- $\quad$ First, it is paramount to understand the political embeddedness, purpose and realworld effects of indicator frameworks and definitions of energy poverty in Europe. To date, the rapidly growing body of scholarship on the measurement and monitoring of energy poverty has rarely considered the specific governing modalities and imaginations associated with this practice.

- Second, and due to the nature of the low-carbon transition and climate challenge in particular, we would argue that energy poverty will need to be connected to nexus approaches in more explicit and direct terms-particularly in terms of its linkages with the "elemental geographies" [111] of water, air, soil and the biosphere.

- Third, there is an acute need to rethink theorizations of the causes of energy poverty so as to expose the wider injustices and policy failures that lead to deprivation and vulnerability [42,44,112-114]. The continued emphasis on behaviour change and education [48] in many policy and scientific debates obscures the persistent and systemic dynamics of stigmatization and exclusion-such as austerity - that lie at the root of the energy poverty problem.

- Fourth, and in a related vein, the notion of "best practices" requires detailed scientific elucidation and evaluation. Recent activities and policy developments as a result of the CEP, for instance, display an increasing tendency towards the fetishization of locally bounded initiatives that are a priori interpreted as successful and effective, without the needed critical cognizance of their broader political grounding and positionality [115].

All of this leads us to conclude that the emergent panoply of "innovative solutions" in the context of climate change mitigation efforts-such as energy co-operatives and communities, prosumers, flexibility and distributed generation-will require careful scientific scrutiny. Appreciating the inherent precarity [116] of energy demand will be indispensable in this context.

Supplementary Materials: The following are available online at https:/ / www.mdpi.com/1996-107 3/14/4/858/s1, Supplementary File for Figure 2 and Table 1.

Author Contributions: Conceptualization, S.B.; methodology, S.B.; validation, S.B., H.T. and M.C.; formal analysis, S.B.; investigation, S.B. and M.C.; writing, S.B. and M.C.; project administration, S.B. and H.T.; funding acquisition, S.B. and H.T. All authors have read and agreed to the published version of the manuscript.

Funding: This paper is based on, and develops insights from, the STEP-IN project, which received funding from the European Union's Horizon 2020 research and innovation programme under grant agreement No. 785125.

Institutional Review Board Statement: Not applicable. 
Informed Consent Statement: Not applicable.

Data Availability Statement: The supplementary data was submitted together with the manuscript.

Acknowledgments: Additional support was provided by the COST Action "European Energy Poverty: Agenda Co-Creation and Knowledge Innovation" (ENGAGER 2017-2021, CA16232) supported by COST (European Cooperation in Science and Technology-www.cost.eu), as well as the EU Energy Poverty Observatory, under contract number ENER/B3/SER/2015-507/SI2.742529 with the European Commission.

Conflicts of Interest: The authors declare no conflict of interest.

\section{References}

1. Bouzarovski, S.; Thomson, H.; Cornelis, M.; Varo, A.; Guyet, R. Towards an Inclusive Energy Transition in the European Union: Confronting Energy Poverty Amidst a Global Crisis; European Commission: Brussels, Belgium, 2020; ISBN 9789276196358.

2. European Commission. Renovation Wave. 2020. Available online: https:/ / ec.europa.eu/energy/topics/energy-efficiency/energyefficient-buildings/renovation-wave_en. (accessed on 1 February 2021).

3. Buzar, S. Energy Poverty in Eastern Europe: Hidden Geographies of Deprivation; Ashgate: Aldershot, UK, 2007.

4. Healy, J. Fuel Poverty and Policy in Ireland and the European Union; Policy Institute, Trinity College Dublin: Dublin, Ireland, 2003.

5. Boardman, B. Fixing Fuel Poverty: Challenges and Solutions; Routledge: London, UK, 2010; ISBN 1-136-54573-5.

6. Clinch, J.P.; Healy, J.D. Alleviating Fuel Poverty in Ireland: A Program for the 21st Century; University College Dublin, Department of Environmental Studies: Dublin, Ireland, 1999; pp. 203-215.

7. Lewis, P. Fuel Poverty Can Be Stopped; National Right to Fuel Campaign: Bradford, UK, 1982.

8. Aristondo, O.; Onaindia, E. Inequality of Energy Poverty between Groups in Spain. Energy 2018, 153, 431-442. [CrossRef]

9. Galvin, R. Letting the Gini out of the Fuel Poverty Bottle? Correlating Cold Homes and Income Inequality in European Union Countries. Energy Res. Soc. Sci. 2019, 58, 101255. [CrossRef]

10. Meyer, S.; Laurence, H.; Bart, D.; Middlemiss, L.; Maréchal, K. Capturing the Multifaceted Nature of Energy Poverty: Lessons from Belgium. Energy Res Soc. Sci. 2018, 40, 273-283. [CrossRef]

11. Petrova, S.; Simcock, N. Gender and Energy: Domestic Inequities Reconsidered. Soc. Cult. Geogr. 2019. [CrossRef]

12. Bollino, C.A.; Botti, F. Energy Poverty in Europe: A Multidimensional Approach. PSL Q. Rev. 2017, 70. [CrossRef]

13. Aranda, J.; Zabalza, I.; Conserva, A.; Millán, G. Analysis of Energy Efficiency Measures and Retrofitting Solutions for Social Housing Buildings in Spain as a Way to Mitigate Energy Poverty. Sustainability 2017, 9, 1869. [CrossRef]

14. Boemi, S.-N.; Papadopoulos, A.M. Energy Poverty and Energy Efficiency Improvements: A Longitudinal Approach of the Hellenic Households. Energy Build. 2019, 197, 242-250. [CrossRef]

15. Bouzarovski, S.; Tirado Herrero, S. The Energy Divide: Integrating Energy Transitions, Regional Inequalities and Poverty Trends in the European Union. Eur. Urban Reg. Stud. 2017, 24, 69-86. [CrossRef]

16. Murias, P.; Valcárcel-Aguiar, B.; Regueiro-Ferreira, R.M. A Territorial Estimate for Household Energy Vulnerability: An Application for Spain. Sustainability 2020, 12, 5904. [CrossRef]

17. Robinson, C.; Mattioli, G. Double Energy Vulnerability: Spatial Intersections of Domestic and Transport Energy Poverty in England. Energy Res. Soc. Sci. 2020, 70, 101699. [CrossRef]

18. Scarpellini, S.; Sanz Hernández, M.A.; Llera-Sastresa, E.; Aranda, J.A.; López Rodríguez, M.E. The Mediating Role of Social Workers in the Implementation of Regional Policies Targeting Energy Poverty. Energy Policy 2017, 106, 367-375. [CrossRef]

19. Castaño-Rosa, R.; Solís-Guzmán, J.; Rubio-Bellido, C.; Marrero, M. Towards a Multiple-Indicator Approach to Energy Poverty in the European Union: A Review. Energy Build. 2019, 193, 36-48. [CrossRef]

20. Thomson, H.; Bouzarovski, S.; Snell, C. Rethinking the Measurement of Energy Poverty in Europe: A Critical Analysis of Indicators and Data. Indoor Built Environ. 2017, 26, 879-901. [CrossRef] [PubMed]

21. Bouzarovski, S.; Petrova, S.; Sarlamanov, R. Energy Poverty Policies in the EU: A Critical Perspective. Energy Policy 2012, 49, 76-82. [CrossRef]

22. Kerr, N.; Gillard, R.; Middlemiss, L. Politics, Problematisation, and Policy: A Comparative Analysis of Energy Poverty in England, Ireland and France. Energy Build. 2019, 194, 191-200. [CrossRef]

23. Kyprianou, I.; Serghides, D.K.; Varo, A.; Gouveia, J.P.; Kopeva, D.; Murauskaite, L. Energy Poverty Policies and Measures in 5 EU Countries: A Comparative Study. Energy Build. 2019, 196, 46-60. [CrossRef]

24. Pye, S.; Baffert, C.; Brajković, J.; Grgurev, I.; Miglio, D.R.; Deane, P. Energy Poverty and Vulnerable Consumers in the Energy Sector Across the EU: Analysis of Policies and Measures; Insight_E: London, UK, 2015.

25. Byrne, J.; Portanger, C. Climate Change, Energy Policy and Justice: A Systematic Review. Anal. Krit. 2014, 36, 315-344. [CrossRef]

26. McCauley, D.; Ramasar, V.; Heffron, R.J.; Sovacool, B.K.; Mebratu, D.; Mundaca, L. Energy Justice in the Transition to Low Carbon Energy Systems: Exploring Key Themes in Interdisciplinary Research. Appl. Energy 2019, 233-234, 916-921. [CrossRef]

27. Bouzarovski, S.; Thomson, H. Energy Vulnerability in the Grain of the City: Toward Neighborhood Typologies of Material Deprivation. Ann. Am. Assoc. Geogr. 2018, 108, 695-717. [CrossRef] 
28. Petrova, S. Illuminating Austerity: Lighting Poverty as an Agent and Signifier of the Greek Crisis. Eur. Urban. Reg. Stud. 2018, 25, 360-372. [CrossRef]

29. LaBelle, M.C. In Pursuit of Energy Justice. Energy Policy 2017, 107, 615-620. [CrossRef]

30. Teschner, N.; Sinea, A.; Vornicu, A.; Abu-Hamed, T.; Negev, M. Extreme Energy Poverty in the Urban Peripheries of Romania and Israel: Policy, Planning and Infrastructure. Energy Res. Soc. Sci. 2020, 66, 101502. [CrossRef]

31. Bonhomme, J.; Seanor, M.; Schinke, R.J.; Stambulova, N.B. The Career Trajectories of Two World Champion Boxers: Interpretive Thematic Analysis of Media Stories. Sport Soc. 2020, 23, 560-576. [CrossRef]

32. Davidson, E.; Edwards, R.; Jamieson, L.; Weller, S. Big Data, Qualitative Style: A Breadth-and-Depth Method for Working with Large Amounts of Secondary Qualitative Data. Qual. Quant. 2019, 53, 363-376. [CrossRef]

33. Peterson, B.L. Thematic analysis/interpretive thematic analysis. In The International Encyclopedia of Communication Research Methods; Matthes, J., Davis, C.S., Potter, R.F., Eds.; Wiley: Hoboken, NJ, USA, 2017; pp. 1-9. ISBN 978-1-118-90173-1.

34. Bednar, D.J.; Reames, T.G.; Keoleian, G.A. The Intersection of Energy and Justice: Modeling the Spatial, Racial/Ethnic and Socioeconomic Patterns of Urban Residential Heating Consumption and Efficiency in Detroit, Michigan. Energy Build. 2017, 143, 25-34. [CrossRef]

35. Bickerstaff, K.; Walker, G.P.; Bulkeley, H. Energy Justice in a Changing Climate: Social Equity and Low-Carbon Energy; Zed Books: London, UK, 2013.

36. Walker, G.; Day, R. Fuel Poverty as Injustice: Integrating Distribution, Recognition and Procedure in the Struggle for Affordable Warmth. Energy Policy 2012, 49, 69-75. [CrossRef]

37. Bouzarovski, S.; Thomson, H.; Cornelis, M.; Rogulj, I.; Campuzano, M.; Goermaere, S. Transforming Energy Poverty Policies in The European Union: Second Annual Report of The European Union Energy Poverty Observatory; EU Energy Poverty Observatory: Manchester, UK; Brussels, Belgium, 2019; Available online: https:/ / www.energypoverty.eu/sites/default/files / downloads / observatory-documents/20-01/epov_pan-eu_report_2019_final.pdf (accessed on 1 February 2021).

38. Jeretina, U.; Uzelac, A. Alternative Dispute Resolution for Consumer Cases: Are Divergences an Obstacle to Effective Access to Justice? Int. Pub. Admin. Rev. 2014, 12, 39. [CrossRef]

39. Bouzarovski, S.; Simcock, N. Spatializing Energy Justice. Energy Policy 2017, 107, 640-648. [CrossRef]

40. Lacey-Barnacle, M. Proximities of Energy Justice: Contesting Community Energy and Austerity in England. Energy Res Soc. Sci. 2020, 69, 101713. [CrossRef] [PubMed]

41. Rademaekers, K.; Yearwood, J.; Ferreira, A.; Pye, S.; Hamilton, I.; Agnolucci, P.; Grover, D.; Karásek, J.; Anisimova, N. Selecting Indicators to Measure Energy Poverty; European Commission, DG Energy: Brussels, Belgium, 2016.

42. Primc, K.; Slabe-Erker, R.; Majcen, B. Energy Poverty: A Macrolevel Perspective. Sustain. Dev. 2019, 27, 982-989. [CrossRef]

43. Bouzarovski, S.; Herrero, S.T.; Petrova, S.; Ürge-Vorsatz, D. Unpacking the Spaces and Politics of Energy Poverty: PathDependencies, Deprivation and Fuel Switching in Post-Communist Hungary. Local Environ. 2016, 21, 1151-1170. [CrossRef]

44. Kod'ousková, H.; Lehotský, L. Energy Poverty in the Czech Republic: Individual Responsibility or Structural Issue? Energy Res. Soc. Sci. 2021, 72, 101877. [CrossRef]

45. Petrova, S.; Prodromidou, A. Everyday Politics of Austerity: Infrastructure and Vulnerability in Times of Crisis. Environ. Plan. C Polit. Space 2019, 37, 1380-1399. [CrossRef]

46. Gillard, R.; Snell, C.; Bevan, M. Advancing an Energy Justice Perspective of Fuel Poverty: Household Vulnerability and Domestic Retrofit Policy in the United Kingdom. Energy Res Soc. Sci. 2017, 29, 53-61. [CrossRef]

47. Bouzarovski, S.; Sỳkora, L.; Matoušek, R. Locked-in Post-Socialism: Rolling Path Dependencies in Liberec's District Heating System. Eurasian Geogr. Econ. 2016, 57, 4-5. [CrossRef]

48. Streimikiene, D.; Lekavičius, V.; Baležentis, T.; Kyriakopoulos, G.L.; Abrhám, J. Climate Change Mitigation Policies Targeting Households and Addressing Energy Poverty in European Union. Energies 2020, 13, 3389. [CrossRef]

49. Feenstra, M.; Özerol, G. Energy Justice as a Search Light for Gender-Energy Nexus: Towards a Conceptual Framework. Renew. Sustain. Energy Rev. 2021, 138, 110668. [CrossRef]

50. Thomson, H.; Snell, C.; Bouzarovski, S. Health, Well-Being and Energy Poverty in Europe: A Comparative Study of 32 European Countries. Int. J. Environ. Res. Public Health 2017, 14, 584. [CrossRef]

51. Oliveras, L.; Artazcoz, L.; Borrell, C.; Palència, L.; López, M.J.; Gotsens, M.; Peralta, A.; Marí-Dell'Olmo, M. The Association of Energy Poverty with Health, Health Care Utilisation and Medication Use in Southern Europe. SSM Popul. Health 2020, $12,100665$. [CrossRef] [PubMed]

52. Kose, T. Energy Poverty and Health: The Turkish Case. Energy Sour. Part B Econ. Plan. Policy 2019, 14, 201-213. [CrossRef]

53. Middlemiss, L.; Ambrosio-Albalá, P.; Emmel, N.; Gillard, R.; Gilbertson, J.; Hargreaves, T.; Mullen, C.; Ryan, T.; Snell, C.; Tod, A. Energy Poverty and Social Relations: A Capabilities Approach. Energy Res. Soc. Sci. 2019, 55, 227-235. [CrossRef]

54. Bolton, P.; Hinson, S. Fuel Poverty; House of Commons Library: London, UK, 2020.

55. Thomson, H.; Simcock, N.; Bouzarovski, S.; Petrova, S. Energy Poverty and Indoor Cooling: An Overlooked Issue in Europe. Energy Build. 2019, 196, 21-29. [CrossRef]

56. Kolokotsa, D.; Santamouris, M. Review of the Indoor Environmental Quality and Energy Consumption Studies for Low Income Households in Europe. Sci. Total Environ. 2015, 536, 316-330. [CrossRef]

57. Ward, K.; Lauf, S.; Kleinschmit, B.; Endlicher, W. Heat Waves and Urban Heat Islands in Europe: A Review of Relevant Drivers. Sci. Total Environ. 2016, 569, 527-539. [CrossRef] [PubMed] 
58. Sanchez-Guevara, C.; Núñez Peiró, M.; Taylor, J.; Mavrogianni, A.; Neila González, J. Assessing Population Vulnerability towards Summer Energy Poverty: Case Studies of Madrid and London. Energy Build. 2019, 190, 132-143. [CrossRef]

59. Horta, A. Automobility and Oil Vulnerability: Unfairness as Critical to Energy Transitions. Nat. Cult. 2020, 15, 134-145. [CrossRef]

60. Martiskainen, M.; Sovacool, B.K.; Lacey-Barnacle, M.; Hopkins, D.; Jenkins, K.E.H.; Simcock, N.; Mattioli, G.; Bouzarovski, S. New Dimensions of Vulnerability to Energy and Transport Poverty. Joule 2021, 5, 3-7. [CrossRef]

61. Besagni, G.; Borgarello, M. The Socio-Demographic and Geographical Dimensions of Fuel Poverty in Italy. Energy Res. Soc. Sci. 2019, 49, 192-203. [CrossRef]

62. Horta, A.; Gouveia, J.P.; Schmidt, L.; Sousa, J.C.; Palma, P.; Simões, S. Energy Poverty in Portugal: Combining Vulnerability Mapping with Household Interviews. Energy Build. 2019, 203, 109423. [CrossRef]

63. Bouzarovski, S.; Tirado Herrero, S. Geographies of Injustice: The Socio-Spatial Determinants of Energy Poverty in Poland, Czechia and Hungary. Post Communist Econ. 2017, 29, 27-50. [CrossRef]

64. Karpinska, L.; Śmiech, S. Conceptualising Housing Costs: The Hidden Face of Energy Poverty in Poland. Energy Policy 2020, 147, 111819. [CrossRef]

65. Scarpellini, S.; Alexia Sanz Hernández, M.; Moneva, J.M.; Portillo-Tarragona, P.; Rodríguez, M.E.L. Measurement of Spatial Socioeconomic Impact of Energy Poverty. Energy Policy 2019, 124, 320-331. [CrossRef]

66. Katsoulakos, N.M.; Kaliampakos, D.C. Mountainous Areas and Decentralized Energy Planning: Insights from Greece. Energy Policy 2016, 91, 174-188. [CrossRef]

67. Katsoulakos, N.M.; Kaliampakos, D.C. The Energy Identity of Mountainous Areas: The Example of Greece. J. Mt. Sci. 2018, 15, 1429-1445. [CrossRef]

68. Sokołowski, J.; Lewandowski, P.; Kiełczewska, A.; Bouzarovski, S. A Multidimensional Index to Measure Energy Poverty: The Polish Case. Energy Sour. Part B Econ. Plan. Policy 2020, 15, 92-112. [CrossRef]

69. EU Energy Poverty Observatory Indicators and Data. 2020. Available online: https://www.energypoverty.eu/indicators-data (accessed on 1 February 2021).

70. Gouveia, J.P.; Palma, P.; Simoes, S.G. Energy Poverty Vulnerability Index: A Multidimensional Tool to Identify Hotspots for Local Action. Energy Rep. 2019, 5, 187-201. [CrossRef]

71. Maxim, A.; Mihai, C.; Apostoaie, C.-M.; Popescu, C.; Istrate, C.; Bostan, I. Implications and Measurement of Energy Poverty across the European Union. Sustainability 2016, 8, 483. [CrossRef]

72. Papada, L.; Kaliampakos, D. Development of Vulnerability Index for Energy Poverty. Energy Build. 2019, 183, 761-771. [CrossRef]

73. Bouzarovski, S.; Petrova, S. A Global Perspective on Domestic Energy Deprivation: Overcoming the Energy Poverty-Fuel Poverty Binary. Energy Res. Soc. Sci. 2015, 10, 31-40. [CrossRef]

74. Sareen, S.; Thomson, H.; Tirado Herrero, S.; Gouveia, J.P.; Lippert, I.; Lis, A. European Energy Poverty Metrics: Scales, Prospects and Limits. Glob. Trans. 2020, 2, 26-36. [CrossRef]

75. Berrod, F.; Navé, L.; Verschraegen, S. The European Parliament and energy poverty: Such a long way to develop a distinctive voice in the Energy Union. In The European Parliament in Times of EU Crisis: Dynamics and Transformations; Costa, O., Ed.; European Administrative Governance; Springer International Publishing: Cham, Switzerland, 2019; pp. 365-385. ISBN 978-3-319-97391-3.

76. Bouzarovski, S.; Petrova, S. The EU energy poverty and vulnerability agenda: An emergent domain of transnational action. In Energy Policy Making in the EU; Tosun, J., Biesenbender, S., Schulze, K., Eds.; Springer: London, UK, 2015; pp. 129-144. ISBN 978-1-4471-6644-3.

77. Dobbins, A.; Nerini, F.F.; Deane, P.; Pye, S. Strengthening the EU Response to Energy Poverty. Nat. Energy 2019, 4, 2-5. [CrossRef]

78. Lakatos, E.; Arsenopoulos, A. Investigating EU Financial Instruments to Tackle Energy Poverty in Households: A SWOT Analysis. Energy Sour. Part B Econ. Plan. Policy 2019, 14, 235-253. [CrossRef]

79. Seebauer, S.; Friesenecker, M.; Eisfeld, K. Integrating Climate and Social Housing Policy to Alleviate Energy Poverty: An Analysis of Targets and Instruments in Austria. Energy Sour. Part B Econ. Plan. Policy 2019, 14, 304-326. [CrossRef]

80. Karásek, J.; Pojar, J. Programme to Reduce Energy Poverty in the Czech Republic. Energy Policy 2018, 115, 131-137. [CrossRef]

81. Creutzfeldt, N.; Gill, C.; McPherson, R.; Cornelis, M. The Social and Local Dimensions of Governance of Energy Poverty: Adaptive Responses to State Remoteness. J. Consum. Policy 2020, 43, 635-658. [CrossRef]

82. Gangale, F.; Mengolini, A. Energy Poverty Through the Lens of EU Research and Innovation Projects; Publications Office of the European Union: Luxembourg, 2019.

83. Longo, D.; Olivieri, G.; Roversi, R.; Turci, G.; Turillazzi, B. Energy Poverty and Protection of Vulnerable Consumers. Overview of the EU Funding Programs FP7 and H2020 and Future Trends in Horizon Europe. Energies 2020, 13, 1030. [CrossRef]

84. European Commission. Communication from the Commission to the European Parliament, the Council, the European Economic and Social Committee and the European Investment Bank. A Framework Strategy for a Resilient Energy Union with a Forward-Looking Climate Change Policy; European Commission: Brussels, Belgium, 2015.

85. European Commission. Vulnerable Consumer Working Group Guidance Document on Vulnerable Consumers, November 2013; European Commission, Vulnerable Consumer Working Group: Brussels, Belgium, 2013.

86. Csiba, K. (Ed.) Energy Poverty Handbook; European Parliament: Brussels, Belgium, 2016.

87. European Parliament. Texts Adopted-Delivering a New Deal for Energy Consumers—Thursday, 26 May 2016. 2016. Available online: https:/ / www.europarl.europa.eu/doceo/document/TA-8-2016-0234_EN.html (accessed on 1 February 2021). 
88. Group of the Progressive Alliance of Socialists and Democrats in the European Parliament; Socialists \& Democrats. Fighting Energy Poverty S\&D Manifesto. 2016. Available online: https://www.socialistsanddemocrats.eu/publications/fighting-energypoverty-sd-manifesto (accessed on 1 February 2021).

89. European Committee of the Regions. Multilevel Governance and Cross-Sectoral Cooperation to Fight Energy Poverty. 2016. Available online: https:/ / cor.europa.eu/EN/our-work/Pages/OpinionTimeline.aspx?opId=CDR-5877-2018 (accessed on 1 February 2021).

90. European Economic and Social Committee. Delivering a New Deal for Energy Consumers (Communication). 2016. Available online: https:/ / www.eesc.europa.eu/en/our-work/opinions-information-reports/opinions/delivering-new-deal-energyconsumers-communication (accessed on 1 February 2021).

91. EUR-Lex. EUR-Lex -32019L0944_EN_EUR-Lex; Publications Office of the European Union: Luxembourg, 2019. Available online: https: / / eur-lex.europa.eu/legal-content/EN/ALL/?uri=CELEX\%3A32019L0944, (accessed on 1 February 2021).

92. EUR-Lex. Regulation (EU) 2018/1999 of the European Parliament and of the Council of 11 December 2018 on the Governance of the Energy Union and Climate Action; Publications Office of the European Union: Luxembourg, 2018; Available online: http: / / data.europa.eu/eli/reg/2018/1999/oj/eng (accessed on 1 February 2021).

93. European Commission. Commission Staff Working Document-Impact Assessment Accompanying the Document Communication from the Commission to the European Parliament, the Council, the European Economic and Social Committee and the Committee of the Regions. Stepping up Europe's 2030 Climate Ambition. Investing in a Climate-Neutral Future for the Benefit of Our People, Part. 1, SWD(2020) 176 Final, 2020. Available online: https:/ / ec.europa.eu/clima/sites/clima/files/eu-climateaction/docs/impact_en.pdf (accessed on 1 February 2021).

94. Hesselman, M.; Tirado Herrero, S. (Eds.) European Energy Poverty: Agenda Co-Creation and Knowledge Innovation. Policy Brief. No. 4: New Narratives and Actors for Citizen-Led Energy Poverty Dialogues; University of Manchester: Manchester, UK, 2020. Available online: http:/ / www.engager-energy.net/wp-content/uploads/2020/09/WG3-Policy-Brief_Sept-2020.pdf (accessed on 1 February 2021).

95. European Commission. Comission Recommendation of 14.10.2020 on Energy Poverty. 2020. Available online: https:/ / ec.europa. eu/energy/sites/ener/files/recommendation_on_energy_poverty_c2020_9600.pdf (accessed on 1 February 2021).

96. European Commission. Commission Staff Working Document EU Guidance on Energy Poverty. 2020. Available online: https:/ / ec.europa.eu/energy/sites/ener/files/swd_on_the_recommendation_on_energy_poverty_swd2020960.pdf (accessed on 1 February 2021).

97. European Commission. Communication from the Commission to the European Parliament, the Council, the European Economic and Social Committee and the Committee of the Regions. Stepping up Europe's 2030 Climate Ambition-Investing in a ClimateNeutral Future for the Benefit of Our People. 2020. Available online: https:/ / ec.europa.eu/clima/sites/clima/files/eu-climateaction/docs/com_2030_ctp_en.pdf (accessed on 1 February 2021).

98. European Commission. Communication from the Commission to the European Parliament, the Council, the European Economic and Social Committee and and the European Investment Bank—Sustainable Growth Strategy. 2020. Available online: https: / / ec.europa.eu/info/system/files/annual_sustainable_growth_strategy_en_0.pdf (accessed on 1 February 2021).

99. European Parliament. European Parliament Resolution of 17 September 2020 on Maximising the Energy Efficiency Potential of the EU Building Stock (2020/2070(INI)). 2020. Available online: https:/ /www.google.com/url?sa=t\&rct=j\&q=\&esrc=s\&source= web\&cd=\&ved=2ahUKEwjPm7a27-ntAhUluqQKHecECNYQFjADegQIBhAC\&url=https\%3A\%2F\%2Fwww.europarl.europa. eu\%2Fdoceo\%2Fdocument\%2FTA-9-2020-0227_EN.docx\&usg=AOvVaw0W24cWJ3K_Ruv8KQioCgXE (accessed on 1 February 2021).

100. European Commission. Long-Term Renovation Strategies. 2020. Available online: https:/ / ec.europa.eu/energy/topics/energyefficiency/energy-efficient-buildings/long-term-renovation-strategies_en (accessed on 1 February 2021).

101. Energy Policy Group. Energy Poverty Today Part. I: Energy Access. 2020. Available online: https://www.enpg.ro/energypoverty-today-part-i-energy-access / (accessed on 1 February 2021).

102. Bouzarovski, S. Transforming Urban Energy Demand: A Timely Challenge. Front. Sustain. Cities 2020, 2, 29. [CrossRef]

103. Angel, J. Irregular Connections: Everyday Energy Politics in Catalonia. Int. J. Urban Reg. Res. 2019, 43, 337-353. [CrossRef]

104. Fundación Ecología y Desarrollo. Spain Lays the Foundations of Its Fight against Energy Poverty; EU Energy Poverty Observatory: Brussels, Belgium, 2020. Available online: https://www.energypoverty.eu/news/spain-lays-foundations-its-fight-againstenergy-poverty (accessed on 1 February 2021).

105. France Nature Environnement. Loi Énergie-Climat: Tout Reste à Faire. 2019. Available online: https://www.fne.asso.fr/ actualites /loi-\%C3\%A9nergie-climat-tout-reste-\%C3\%A0-faire (accessed on 1 February 2021).

106. Tsui, J. COVID-19 Pandemic Shows How Important Energy Equality Is. Environmental Protection. 14 April 2020. Available online: https: / / eponline.com/articles/2020/04/14/covid19-pandemic-shows-how-important-energy-equality-is.aspx (accessed on 1 February 2021).

107. Baker, W.; Ambrose, A.; Brierley, J.; Butler, D.; Marchand, R.; Sheriff, G. Focus Article—Stuck at Home in a Cold Home: The Implications of Covid-19 for the Fuel Poor. PPP 2020, 14, 2-5. [CrossRef]

108. Hesselman, M.; Varo, A.; Guyet, R.; Thomson, H.; ENGAGER COST Action. Global Map of COVID-19 Household Energy Services Relief Measures. 2020. Available online: Engager-energy.net/covid19 (accessed on 1 February 2021). 
109. Frantzeskaki, N.; Loorbach, D.; Meadowcroft, J. Governing Societal Transitions to Sustainability. Int. J. Sustain. Dev. 2012, 15, 19-36. [CrossRef]

110. Meadowcroft, J. What about the Politics? Sustainable Development, Transition Management, and Long Term Energy Transitions. Policy Sci. 2009, 42, 323-340. [CrossRef]

111. Jackson, M.; Fannin, M. Letting Geography Fall Where It May-Aerographies Address the Elemental. Environ. Plan. D 2011, 29, 435-444. [CrossRef]

112. Bouzarovski, S.; Frankowski, J.; Herrero, S.T. Low-Carbon Gentrification: When Climate Change Encounters Residential Displacement. Int. J. Urban Reg. Res. 2018, 42, 845-863. [CrossRef]

113. Grossmann, K. Using Conflicts to Uncover Injustices in Energy Transitions: The Case of Social Impacts of Energy Efficiency Policies in the Housing Sector in Germany. Glob. Trans. 2019, 1, 148-156. [CrossRef]

114. Recalde, M.; Peralta, A.; Oliveras, L.; Tirado-Herrero, S.; Borrell, C.; Palència, L.; Gotsens, M.; Artazcoz, L.; Marí-Dell'Olmo, M. Structural Energy Poverty Vulnerability and Excess Winter Mortality in the European Union: Exploring the Association between Structural Determinants and Health. Energy Policy 2019, 133, 110869. [CrossRef]

115. Bouzarovski, S.; Haarstad, H. Rescaling Low-Carbon Transformations: Towards a Relational Ontology. Trans. Inst. Br. Geogr. 2019, 44, 256-269. [CrossRef] [PubMed]

116. Petrova, S. Encountering Energy Precarity: Geographies of Fuel Poverty among Young Adults in the UK. Trans. Inst. Br. Geogr. 2017, 43, 17-30. [CrossRef] [PubMed] 